\title{
May Your Liver Come Out of Your Mouth! A Corpus Based Study: Curse Structures in Turkish Utterances
}

\author{
Ciğerin Ăgzından Gele! \\ Türkçe Beddua Yapıları: Derlem Tabanlı Bir Çalışma
}

Hülya ÜNSAL ŞAKİROGLU*

\begin{abstract}
Corpus can be described as a database for the purpose of research. Corpus studies have now been used in nearly every field of linguistics since the 1970s and gradually becoming a part of linguistic terminology. In present study cursing elements of Turkish language were searched employing Turkish National Corpus. Cursing is an interesting subject matter that attracts several areas of linguistics not only micro fields such as, semantics, and syntax but also macro divisions such as psycholinguistics, discourse and pragmatics. In this study, we attempt to investigate the unique features and the most common use of curse utterances in Turkish and variations across regions, to understand if social variables such as age, gender and education level have influence on what cursing structures are used, and to find out whether survey results and national corpus are consistent in curse utterances. Data was collected via Turkish National Corpus and survey was developed based on array of research questions and applied to 170 participants. The findings derived from corpus and survey indicate similar features as particular curse words such as beddua (cursing), kahretsin (damn) and bela (trouble-evil) observed more often than kargış (imprecation), ilenme (cursing), mahvetsin (ruin). In parallel with the survey result, the most frequently used curse utterances in the Turkish National Corpus were Allah belanı versin, Allah cezanı versin, kahretsin (damn you, God punish you, damn it). In addition, distinctive curse structures varying from region to region were conceived.
\end{abstract}

Key words: Corpus-Based Approach, Curse Utterances, Speech Act theory, Local Cursing Terminology

\section{ÖZ}

Araştırma amaçlı bir veri tabanı olarak tanımlanabilen derlem çalışmaları 1970'lerden itibaren dilbilimin hemen her alanında kullanılmaya başlanmış ve giderek dilbilimsel terminolojinin bir parçası hâline gelmiştir. Bu çalışmada, Türk Milli Derlemi kullanılarak Türkçedeki beddua unsurları araştırılmıştır. Beddua, dilbilimin sadece anlambilim ve söz dizimi gibi mikro alanlarını değil; psikodilbilim, söylem ve pragmatik gibi makro alanlarını da çeken ilginç bir konudur. Bu çalışmanın amacı, Türkçedeki beddua sözlerinin kendine has özelliklerini ve bölgelere göre varyasyonlarını ortaya çıkarmak; yaş, cinsiyet ve eğitim düzeyi gibi sosyal değişkenlerin hangi beddua yapılarının kullanıldığı üzerinde etkisi olup olmadığını göstermek; anket sonuçlarının ulusal derlemde yer alan beddua ifadeleriyle tutarlı olup olmadığını tespit etmeye çalışmaktır. Veriler, Türkiye Ulusal Derlemi aracılığı ile ve bir dizi araştırma sorusuna dayalı olarak geliş̧irilen anketin 170 katılımcıya uygulanmasıyla toplanmıştır. Derlem ve anketten elde edilen bulgular, beddua, kahretsin ve bela gibi belirli beddua sözcüklerinin kargış, ilenme, mahvetsin sözcüklerinden daha sık görülmesi gibi benzer özellikler göstermektedir. Anket sonucuna paralel olarak Türk Ulusal Derlemi'nde en sik kullanılan beddualar Allah belanı versin, Allah cezasını versin, kahretsin olarak saptanmışıtır. Ayrıca bölgeden bölgeye değişen kendine özgü beddua yapılarına da rastlanmıştır.

Anahtar kelimeler: Derlem Temelli Yaklaşım, Beddua Sözleri, Söz Eylem Teorisi, Yerel Beddua Terminolojisi

\footnotetext{
* Öğr. Gör., Kafkas University, School of Foreign Languages, Kars, Turkey hulyaunsal@kafkas.edu.tr Orcid: 0000-
} 0003-0252-1275 


\section{Introduction}

Cursing is defined as asking God for letting someone who is not loved to be in a bad state. It is the opposite of blessing. Cursing is also described as asking God or a divine force to hurt someone (Nezakat-Alhossaini \& Esslami-Rasekh, 2013). When looking at curse in meaning, negative emotions are at the forefront and there is a state of trust in God or a divine power and demanding that power to bring curse, trouble, death, disease, misery, solitude to the person being cursed. The curse does not consist of very long sentences as common words are used (Atmaca, 2019).

The curse is fundamental to the theory of the act of speech of Austin. Austin (1962) categorizes curse words as actions in his classification of words based on their illocutionary meaning, and adds that behabitives are associated with attitudes and social conduct. Cursing utterances are culturally distinctive utterances that exist more or less commonly in one culture than another. The choice of the cursing words depends on the community's available socio-religious belief and is a remarkable mode of linguistic form (Nezakat-Alhossaini \& Esslami-Rasekh, 2013).

The curse is a product of the false oath; it refers to the grasping power of the word the oath stands for. If the binding force of the language was referred to the language of Austin, the guidelines of the performing act towards convention were to be seen. Austin describes the conditions of the success of a performative utterance as follows:

"There must exist an accepted conventional procedure having a certain conventional effect and that procedure to include the uttering of certain words by certain persons in certain circumstances, the particular persons and circumstances in a given cause must be appropriate for the invocation of the particular procedure invoked. The procedure must be executed by all participants both correctly and completely."

The performative's normative commitment to convention can be understood as an oath structure. The bond to the convention ensures that the act of speech is effective, as the convention itself confirms. Then the curse will find its place in a break with convention: "Now if we sin against any one of these [...] rules, our performative utterance will be (in one way or another) unhappy" (Strowick, 2016). 
Just as the feeling of gratitude and in the face of goodness is expressed through prayers and wishes, when the emotions and thoughts are not wanted to be applied due to inadequacy, the response is found in the form of bad wishes and swearing to just hurt. In the event that physical power is not sufficient, the existence of a spiritual power is accepted and the person responds by requesting help from the mighty forces. "Curse" is a violent reaction of man against people who will harm him, his community, his family, and his institutions such as religion. The curse utterances were eloquently described by Beyazit (2019) as " In most of these, the addressee of the conflict is referred to Allah (God), while in some; the interlocutor is confronted with the wrath of the archaic god and magical power" (Beyazıt, 2019).

Society's beliefs also have an impact on cursing certain ground. Another feature in the words of cursing is referring to "euphemism" in a narrative to alleviate and refine words by replacing the words that are considered as shame or sin by using conventional and meaningless bad words. Therefore, it is understood that many chaos has come out of the words of swearing. Curse utterances can be a very rich source for verbal reflection of the cultural identity of a group, because they show many facets of the language, culture and way of thinking of the people who belong to the speech group. It should also be noted that the speech acts used in cursing are not common, as the culture and belief of one group is different from others (Devi, 2019).

Corpus-based inquiry assumes the validity of the language forms and structures derived from the theory of linguistics. The main aim of research is to examine the systemic patterns of variation and use for those linguistic features that are predefined. Corpus-driven work is more inductive, such that the linguistic framework itself arises from a corpus analysis.

Corpus linguistics is a study paradigm that has emerged in recent decades to encourage empirical research into language diversity and use. Corpus studies employ two research approaches: corpusbased and corpus-driven. In corpus-based research, the validity of language forms and structures established from linguistic theory is assumed. The primary purpose of the research is to explore systemic variational patterns and employ them for identified language properties. The linguistic framework emerges from corpus analysis in corpus-oriented work, which is more inductive in character (Biber, 2012). 
A number of studies across various regions targeted the curse structures in different languages. Alhossaini and Rasekh (2013) explored the role of cursing as a language act in Persian along with the social and cultural underlying principles. The data from the 90 men and women participants were obtained using an open discourse completion task (DCT) of eight circumstances and individual interviews. The study concluded that women used cursing more often than the men. Participants with relatively lower educational level applied curse utterances more frequently than those with higher education levels (Nezakat-Alhossaini \& Esslami-Rasekh, 2013).

In another study, the features and functions of curse utterances in the language of Meiteis in Manipur were investigated. The common instances of Meiteilon's curse were discussed through speech act theory therefore communication ethnography and the underlying social and cultural values were revealed. The paper was built on Austin's speech act theory so that it would be possible to fully explain "the total speech condition". In comparison to other speech act, an alternative scheme was suggested to describe illocutionary acts in terms of various aspects of the speech situation. After initially addressing the situation of speech and its theoretical meaning, and subsequently using Austin's conditions of congratulations as a starting point, the author described three aspects of the state of expression, conventionality, actuality and intentionality according to which a supposed act succeeds (Devi, 2019).

Curse utterances are a striking form of language. While some languages have few curse utterances, other languages, such as Turkish, are well known for their inventive and multiple curse terms. A number of studies targeted various aspects of curse usage in Turkish (Keskin, 2019). In the research on Turkish dialects of eastern groups conducted by Ersöz (2011), the relationship between curse functions and sentence patterns was explored. The "target person" could be "you (anyone else but the speaker)", "I (the speaker himself)" or "nobody" and the "context" in which the bad wish in the curse was directed in determining on purpose of curse usage were effective. A classification has emerged as follows; the curse function (Target person is the person opposite the speaker) including full curse and curse like prayer. Secondly, oath and stiffening function (Target person is the speaker himself) oath curses and slimming curses, lastly, profanity function (Target person is no one). The correlation was found between the functions of the eastern dialects of Turkey and sentence structures of those curse functions. The results revealed that not all functions can be used in every sentence structure: It has been determined that the curse in speech language is used in full curse, 
prayer, oath, defeat and profanity functions. There are some principles of transformation of functions between each other. There is a relationship between sentence structures and preferences of modal suffixes in these structures. Some functions are captured in certain sentence structures with specific modal suffixes (Ersöz, 2011).

In a study by Atmaca (2019), the prayers and curses were defined in terms of context, and subsequently analyzed in terms of form, and a general assessment of the usage of prayer and curses in Antalya's dialect were completed in the light of numerical data. The data regarding the 307 curses were categorized as curses about death, with torment and persecution, general curses, about kinfolks, regarding the bad diseases, curses wishing the addressee's disability, curses post-death and evil in the hereafter, about marriage, curses wish on the addressee's remain homeless and the destruction of the his home, curses used as profanes, curses which wish their addressee to be harmed by animals, those wished poverty to their interlocutor, the ones on eating and drinking, the addressee's harms by a weapons, curses which wish the other party to die with the tool, curses about old age, wishes that the addressee's needs, curses that wishes madness for the addressee, curses which wished to slander his addressee, curses that wishing goodbye to the addressee, curse voices for people who do immoral (Atmaca, 2019).

The features and functions of curse utterances in Turkish were also investigated by analyzing concrete examples using principles from the theory of speech actions and communication ethnography. The researchers tried to address Turkish curses using HYMES (1974) parameters. The study demonstrated that curse utterances are more than linguistic rituals, as they allow their "addressors" to enjoy a high degree of creativity and verbal versatility within very strict morphological and syntactic rules (Vanci-Osam, 1998). The research concluded that the curse statements are similar to other speech acts with some distinctions. One such distinction is, for instance, to the sender (addressor) rather than the recipient (Addressor) in cursing the perlocutionary act. The connection between a person's social context and the use of this speech act is another observation on cursing in Turkish. The use of curse utterances in speech generally does not seem appropriate and polished, and it projects in the addressee's personal characteristics such as rudeness and aggressiveness. In the spoken language of their standard nature it is still a normal occurrence, despite negative images associated with curse utterances (Vanci-Osam, 1998). 
In the study conducted by Uysal (2019) a total of 109 prayers and 257 curse examples in Turkish were investigated. The examples were classified based on the semantics and the person to whom the prayers/curses were directed. The most obvious feature was that the blessing (acclamations) is entirely requested from God and curses (imprecations) on the other hand are intensely based on the collocutor. When evaluated in terms of language features, it was observed that Adiyaman prayer and curse structures included many local dialect features in their content. There are examples in both prayer and curse samples that are adopted and addressed widely in the society. The most critical characteristic of these structures is that all praise is sought by God or addressed to Him. On the other hand, the impressions are based extensively on the collocutor (Uysal, 2019).

Despite a number of aforementioned local and targeted studies, no study aimed to reveal a nationwide pattern of cursing elements scanned in real time. Several studies investigated phonological or morphological aspects of the corpora in literature. Nonetheless, there is a lack of corpus based approach as a complementary tool for analyses of cursing pattern in Turkish. Therefore, studies of cursing both supported by corpora and survey across the language hinterland are rare.

The purpose of this research was to find out more about the general features of cursing among a wide range of Turkish speakers and effects of demographic factors on cursing behavior. The study also investigated the corresponding structure of curses in the Turkish Corpus. Research Questions are;

I. What are the most frequent curse utterances as well as the features of them in Turkish and how they differ among regions?

II. Do social variables such as age, gender, and educational level have an impact on the cursing structures used?

III. Are curse utterances in survey findings consistent with curse structures among written and verbal sources in the national corpus?

\section{Method}

The study is designed to have two different data tools as corpus based data source and survey questions. 


\subsection{The survey}

The first tool to collect data was the survey that was developed by the researcher to elicit the answers of the research questions. The survey was designed in a way the participants to interpret several open ended questions. Data was collected via e-mail and social media networks. Respondents were volunteers across Turkey. The survey was shared with 170 participants using online tools and responses were collected in an analogous manner. Open-ended questions are preferred when participants are asked to answer freely. The open-ended questions, also known as non-structured questions with an advantage of to get answers that are not expected or planned that ultimately could contain more detailed information about the subject. The disadvantage of openended questions is that the time elapsed in answering the question, data handling and analyses. Open-ended questions can be grouped into interpretation, listing and filling in gaps (Mertens, 2014). In this study we chose to employ interpretation type open-ended questions.

\subsection{Turkish National Corpus (TNC)}

In this study, the dependent indexes of the curse words in Turkish were taken in contextual keyword view via TUDv3 (Aksan et al., 2012). The search on the review was carried out in all of the texts in the context-dependent and everyday speech fields, written between 1989 and 2013, consisting of a total of 50,400,476 words which consists of texts generated in a variety of disciplines on a variety of themes. TNC's database includes spontaneous, every-day conversations and speeches captured in specific communicative settings, and transcriptions from spoken data make up $2 \%$ of the total.

After key terms regarding to cursing are determined, both verbal and written data source were checked using Turkish National Corpus and were subsequently analyzed in the contexts of cursing discourse.

\subsection{Data Analyses}

The effect of binary demographic variable (gender) and categorical variable (education level) on the cursing behavior traits were assessed using Chi-square test. The effect of continuous variable (age) on the cursing behavior traits were assessed using logistic regression approach. SAS (9.4), a 
statistical analysis software, was used for all of the analyses. An experiment-wise error rate of $\alpha=0.05$ (or $p$-value of 0.05 ) was considered as a cut-off value for assessment of the significance.

\section{Results}

\subsection{Survey outcomes}

We initially aimed to deduce a general pattern of cursing behavior among a broad range of Turkish speakers. A total of 170 people participated to the study however 13 were incomplete answers and were removed prior to the analyses. Thus final number of respondents included in the further analyses was 157 . The respondents who attended in the study were from variety of provinces including seven geographical regions of Turkey. The number of different provinces where participants took part in survey was 40 (out of 81 provinces in Turkey) reflecting a wide coverage of the entire population. The participants were composed of 112 females and 44 males. There are 31 graduate students /degree holders and 93 college students/college graduates. While the number of high school graduates was 19, seven secondary school graduates and only 4 primary school graduates participated. Participants' ages range from 15 to 66 with a mean of $32.40 \pm 9.93$.

In this research it is verified whether demographic variables affect aspects of cursing behavior. We initially tested if gender has any influence on whether the participants curse or not. Our second query was that in which situation participants use imprecations. Thirdly, we examined potential differences in the participants' perception of why people use malediction. Last question was how they mostly curse. The results revealed that gender did not have an effect in the responses to any of questions except the perception of why people use malediction and the choice of the curse (Table $1)$.

Table 1. Chi-Square analyses for evaluating the effects of gender on cursing habit, cursing frequency, and preference of cursing words

\begin{tabular}{lccc}
\hline Question & DF & Chi-Square Value & p- value \\
\hline Do you curse? & 1 & 1.18 & 0.28 \\
In which situations do you curse? & 12 & 17.77 & 0.12 \\
Why do you think people curse? & 17 & 28.44 & 0.04 \\
How do you most frequently curse? & 21 & 35.07 & 0.03 \\
\hline
\end{tabular}


We also tested whether the effects of education level on cursing habit, cursing frequency, and preference of cursing words were significant. First inquiry was if they ever curse. Another question was that on what circumstances they use imprecations. Thirdly, we have asked participants what they think how people use of malediction. The last question was that what cursing utterance they frequently use. Similar to gender effect, the education level had only one significant effect $(\mathrm{p}=0.01)$ that was on the perception of the reason for cursing (Table 2).

Table 2. Chi-Square analyses for evaluating the effects of education level on cursing habit, cursing frequency, and preference of cursing words.

\begin{tabular}{lccc}
\hline Question & DF & Chi-Square Value & p- value \\
\hline Do you curse? & 4 & 0.52 & 0.97 \\
In which situations do you curse? & 48 & 50.42 & 0.38 \\
Why do you think people curse? & 68 & 95.97 & 0.01 \\
How do you most frequently curse? & 84 & 73.38 & 0.79 \\
\hline
\end{tabular}

The effects of age on habit of cursing, frequency, and cursing words have also been considered. The first question was whether they ever use maledictions. Our second question was on what cases the participants use malediction. Next, we have asked participants how they think about the use of malediction. The last question was what cursing utterances they mostly use. The logistic regression results indicated that except the first query $(\mathrm{p}=0.53)$ all other quests were effected from the age $(\mathrm{p}<0.001)($ Table 3).

Table 3. Logistic regression analyses for evaluating the effects of age on cursing habit, cursing frequency, and preference of cursing words.

\begin{tabular}{lllc}
\hline Question & Chi-Square Value & DF & p- value \\
\hline Do you curse? & 0.39 & 1 & 0.53 \\
In which situations do you curse? & 168.82 & 11 & $<.0001$ \\
Why do you think people curse? & 202.30 & 15 & $<.0001$ \\
How do you most frequently curse? & 300.70 & 20 & $<.0001$ \\
\hline
\end{tabular}


We further analyzed the significant results in depth to assess the pattern that led the significance through figures.

Figure 1 provides the distribution of the responses to "why people curse" by gender variable. There were several discrepancies of reasons why the participants think people curse based on gender. Each of different answers provided by the participants was coded in numbers and numbers were demonstrated in the figures. The number 1 corresponded to response that "when they feel unwell, if they experience something bad, when their bad sides arise", number 2 represents "when they are angry, mad, and couldn't control their rage, to relax/ to calm the nerves", number 3 is "in the face of injustice, when their power is not enough, when they feel helpless", number 4 stands for "when their hearts are broken and sad and hurt", number 5 corresponds to "being negatively affected, when they suffer of something and are disappointed", number 6 is the response "I do not know", number 7 represents "to be wronged", and number 8 stands for "because of unconsciousness, escape psychology, not being patient". The answers of why people use cursing structures appear to be largely parallel to relative distribution of the gender (numbers of male (44) and female (112) attendants) since the ratio seems to be close to $1 / 3$. When the frequency of different curse types analyzed, a higher elevation in the frequency of some curses were evident while a wide range of rare curses were also encountered. When the analysis restricted to their relative frequency between males and females, it was found that some contrasting frequencies were present. For instance, the reason 5 (being negatively affected, when they suffer of something and are disappointed) were used by females at a higher frequency than males. The reason number 11 (because of envy, jealousy and arrogance) was detected to be higher among males than females. It is rather unexpected for males to state envy and jealousy as a reason for cursing compare to females. 


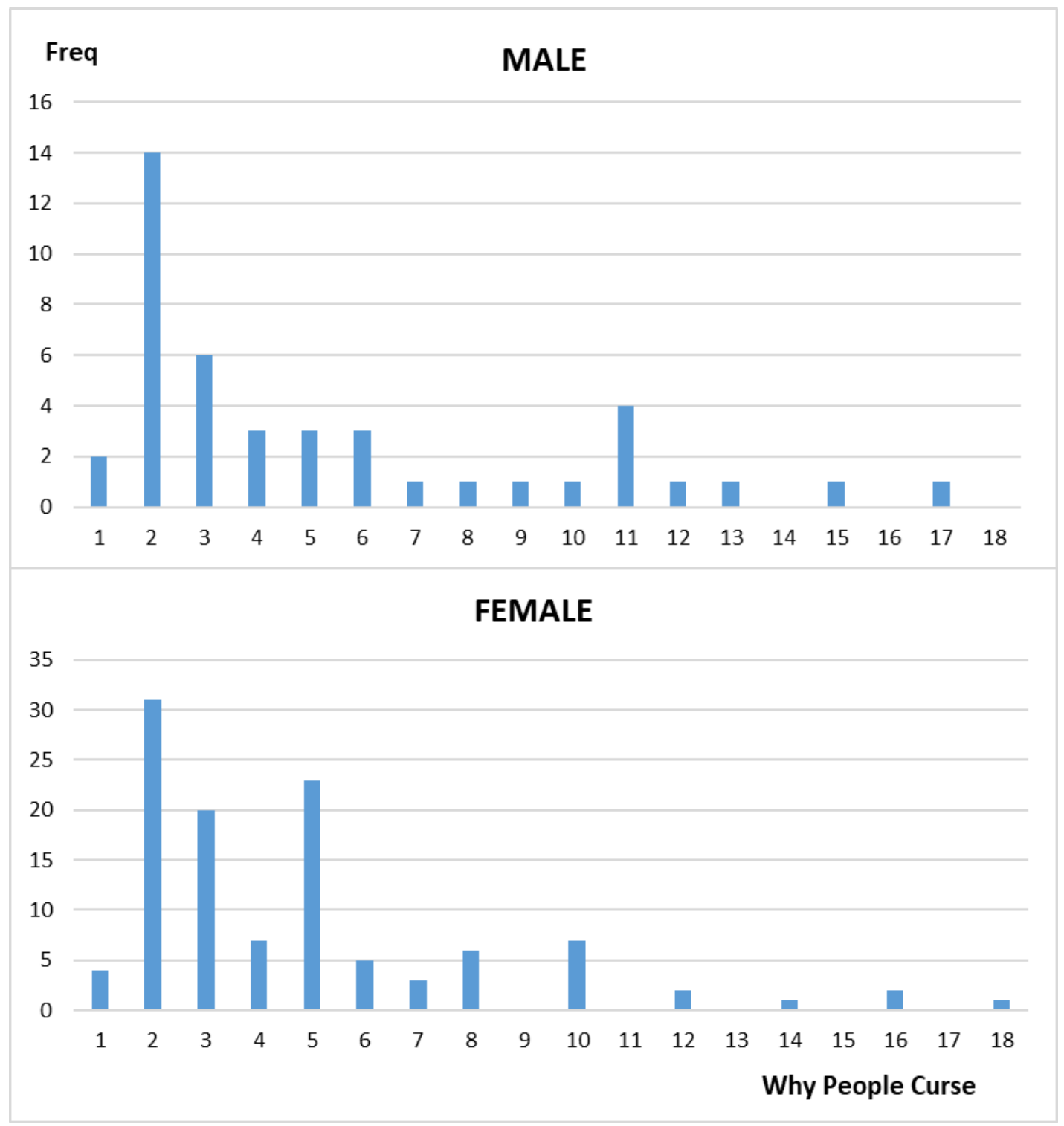

Figure 1. The relative frequency distribution of the reasons of cursing across two genders.

The distribution of most frequent curse utterances participants use by gender indicate similar results on number 1 (there is no), when people do not use cursing at all with the percentage of $6 \%$ for males and about 25\% for females. The curse number 2 (Allah belanı, cezanı versin-damn you, may God punish you) was used $13 \%$ by males and $17 \%$ by females indicating a relatively higher frequency among female participants. A similar pattern was evident for statement 8 (Allahından bul, Allah seni bildiği gibi yapsın, Allah müstehakını versin-Find it from God! May God make you as he knows, May God give you what you deserve) where $2 \%$ of males and $14 \%$ of females (relatively higher frequency) indicated using the statement. Yet another similar pattern was present 
in the statement 3 (Allah sana aynısını yaşatsın, Allah sana fazlasını yaşatsın; sen de üzül; Allah sana misliyle yaşatsın -May God give you the same, May God give you more, and you will be sad and May you experience difficulty you created with an order of magnitude) where $1 \%$ and $4 \%$ indicated usage among males and females, respectively. Curse number " 6 " was uttered $2 \%$ by females while it was not practiced by males at all (Allah iyiliğini versin-God give you goodness). The statement number 9 (Allah'a havale ediyorum-I refer (everything or you etc.) to God) was used with $1 \%$ and $4 \%$ by males and females, respectively. The curse statement coded by number 19 (Kahrolsun, Allah Kahretsin-damn, God damn you-it, etc.), structure was written by 3\% by females seems to be a completely female curse as it was not used by any male.

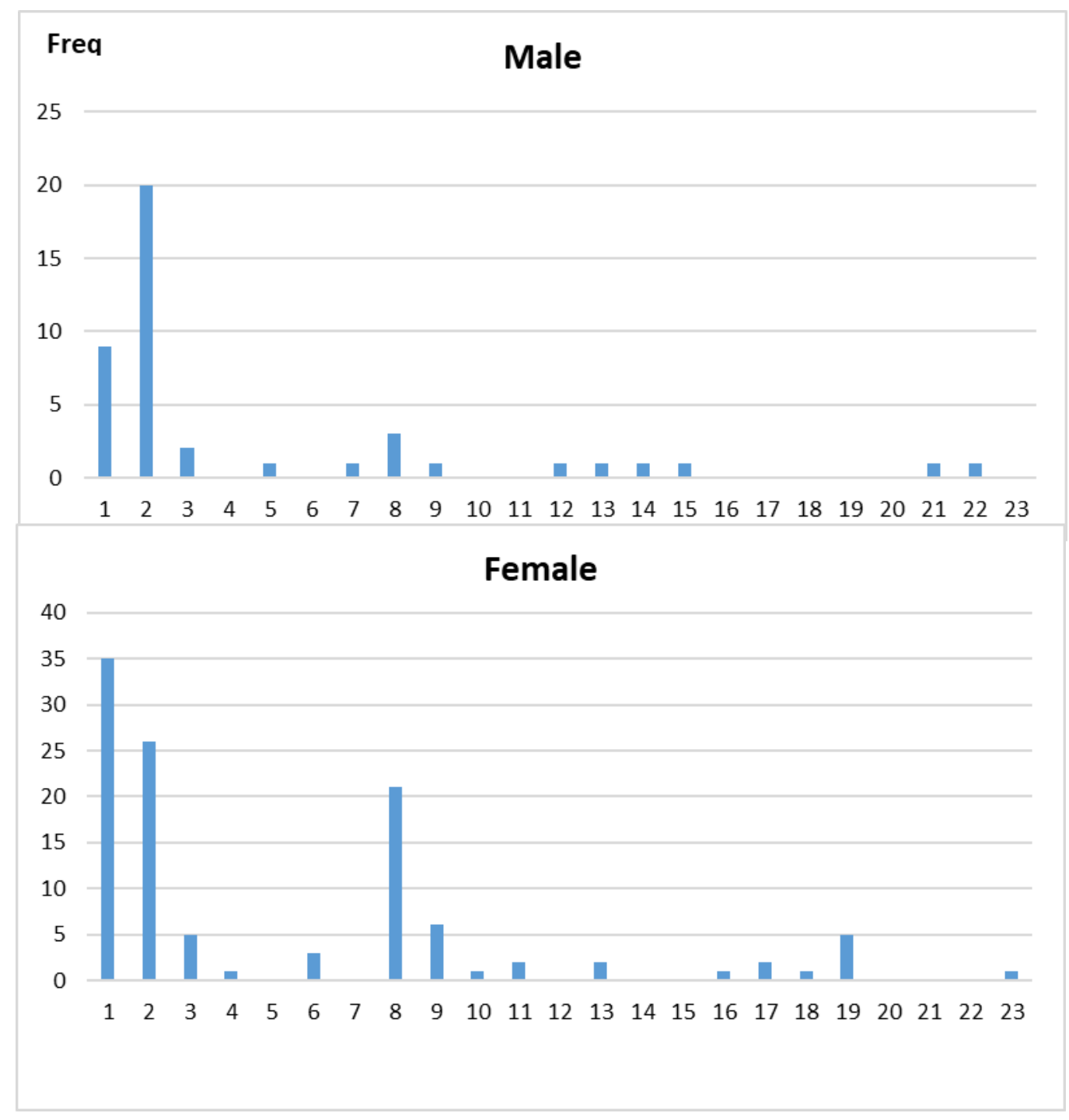

Figure 2. The relative frequency distribution of the most frequent curses across two genders. 
Mersin Üniversitesi Sosyal Bilimler Enstitüsü e-Dergisi Cilt: 5 Sayı:1/Aralık 2021
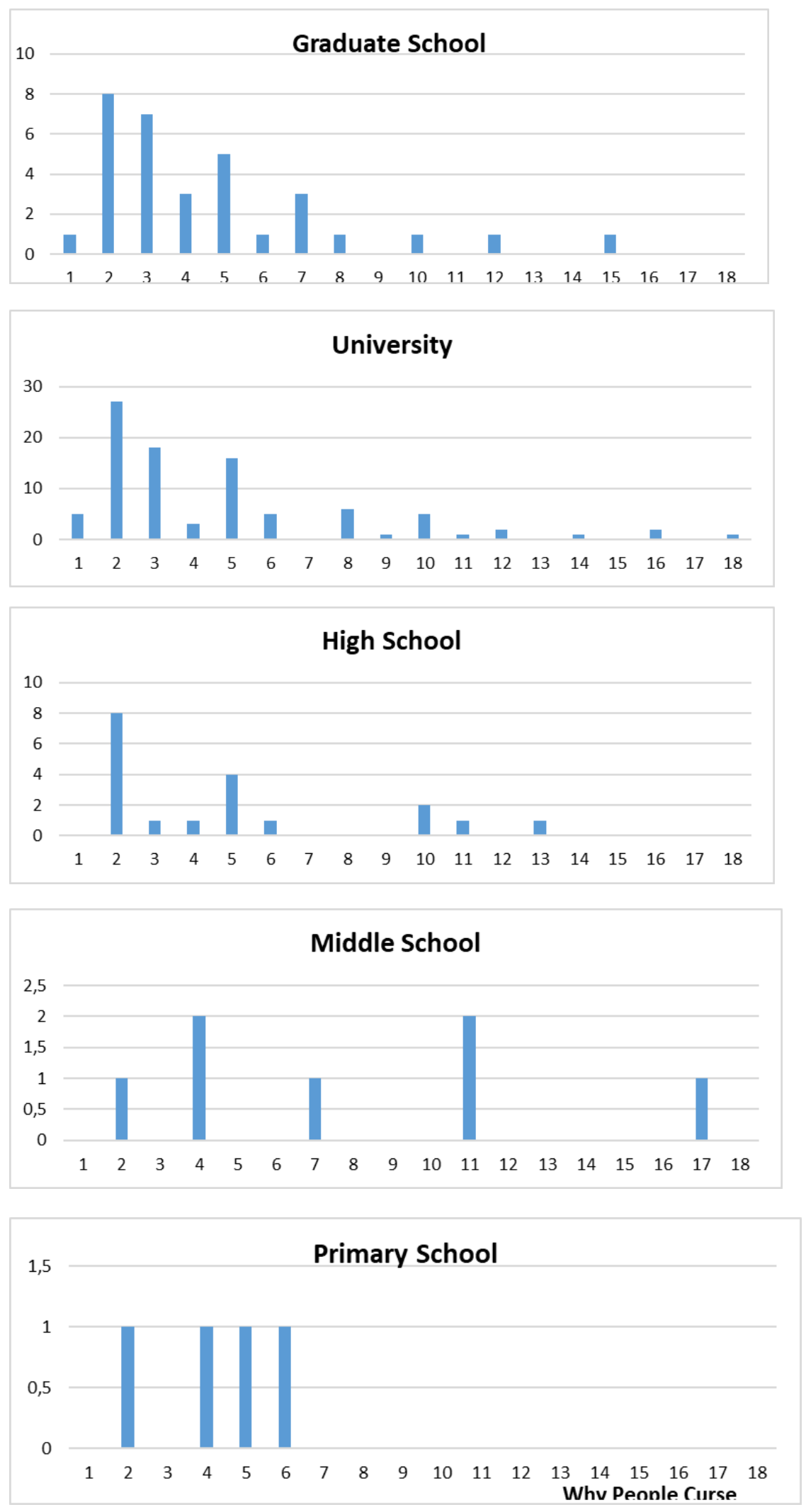
Figure 3. The relative frequency distribution of the most frequent curses across different education level.

When the effect of the level of education on the reasons of cursing evaluated in depth, it was found that different education levels prioritize divergent reasons for cursing. For example, a relatively much higher frequency of reason 2 (when they are angry, mad, and couldn't control their rage, to relax/ to calm the nerves down) was indicated to be the motivation of cursing among high school graduates compare to other groups. Similarly, reason 11 (envy, jealousy) was cited more frequently among secondary school graduates. Furthermore, reason 5 (being negatively affected, when they suffer of something and are disappointed) was more frequent reason of cursing among college students.

\subsection{Regional differences of curse structures in Turkey}

The survey also provides some results about local variation and use of cursing utterances of Turkey. We encountered responses from 40 provinces in all seven geographic/cultural regions. Results indicate both similarity in practicing common curse utterances such as God damn you and vary in vernacular language as they are listed below. Eastern Anatolia Region borders four countries with four different alphabets and cultures. Therefore, the region has many isolated cultural and lingual groups and developed a set of very distinct curse utterances. Davun değe -may you be throat cancer, Kamyon altında kalasın- may a truck crash you, ellerin kırlla yanına uzana- may your hands be broken and never move, vurucun vura- may you hit by shooter (Erzurum), Dalın (belin) kırılsın/ boynun şişsin, boynun altında kalsın, okulun kara gelsin, Toprak başına, Başın batsın, Zıkkımın kökü, Çor, Karnında kara haşil kaynasın, vurgun vursun, başın batsın-may your head get down in earth, die (Kars) Sürüm sürüm sürünesice (Elazı̆̆ )-may you be crippled, Allahından bul- find your trouble from god (Hakkari), Yanın yere gele- may you fall down on your side (means you die), yetişemiyesice-may you not reach to where you aim (Malatya), Toprax başan-may you die, Allah tependen baksın (expression to reflect anger without curse and trouble) (Muş) and Allah hakkımı senden çıkarsın-May God get my right from you, tepen delinsin, boynun altında kala, (Van) Dört gişinin omzunda gedesin-may you be carried over shoulders of four (means die) were the examples of authentic curses restricted to the region.

The curse "Ander Kalsin" (Artvin) is a local cursing utterance used in the eastern Black Sea to mean stay away, damn it. Allah kabız etsin, teneşir paklasın/Allah seni davul etsin (Bartın) mean 
may you be constipated/may you die/may your skin used for drum and Allah ala seni-may god take your life (Gümüşhane), Allah ovdumasın (Ordu), Adun çesulsun-may nobody remember your name, Allah seni alsun- may god take you, Allah seni bildiği gibi yapsun- May God do(work) on you how he knows (wants) it (Rize), and Boyun devrilsin- may you tumble down (hoping someone you don't like to fall over like a log) (Samsun) are used in western Blacksea Region.

Allah canını ala (May God take your life) (Denizli), kaynanan başına kalsın -may you have to look after your mother-in-law (İzmir). Gözü çıkasıca, Allahından bulasıca, yerin dibine batasıca, can'ın çıksın used in Aegean Sea Region and mean respectively that may you lose your eyes, find your trouble from God, get into the ground, may your life come out.

Allah belanı kaldırsın-god bless you, Allah seni bildiği gibi yapsın- May God do on you how he wants it (Tekirdağ) and beter ol-be worse (Edirne) were local curse utterances of Marmara region.

Allah canını alsın-May Allah take your life, Geberesin (may you die like animal) Adın batsın (may your name forgotten). Dember dember dönesin. Töremeyesin - may you not reproduce, Çenen çekilsin- this word is based on the jaw of the dead; wishing addressee die and people tie his mouth so there will be silent because it usually is uttered the result of nagging, Saçı sakalı ăgırasıca-may you get aged, Boğazına durasıca-may you choke, Geberesice, (may you drop dead) boyu posu devrilesice/devrilsin (a word of curse to mean death, May addressee and descendants of his entire family die), Ciğeri yansın (to suffer greatly from); to feel great compassion for), Gulana gurşun akasica-may lead fill in your ear (means be deaf) (Antalya) are some common curse structures in Mediterranean Region.

Karaltısı kalkasıca-may you die so there will not be your shadow anymore (Kahramanmaraş), Ömrü kesilesice (Kayseri), vurgunun yiğin gelsin-may you have stroke, yaşı gara gelesice- may you see bad days as you live (Konya), Yuvanda baykuş ötsün-Let the owl sing in your nest (may no one left in your family) Allah gul defterinden silsin-May God delete your name from his servant book, Namazını kıldıracak bulunmasın- may there be no one to perform your death prayer (Aksaray), were used only in Central Anatolia Region.

Kara yerin dibine giresice (Kilis)-may you get in the bottom of black earth, beni ginayan benim köyneğimi giysin-may whoever judge me be just like me, kepeği kesilesice-may you not find 
livelihood (Gaziantep), Allah ne bu dünyada ne de ahirette gün yüzü göstersin-May god let you have a good day neither in this world nor hereafter (Mardin), Lime lime olasin- may you be tattered and torn, Kırk çalıpta kudurasıca (Şanlıurfa) were the unique cursing statements used in the Southeastern Anatolia Region.

\subsection{National Corpus}

Curse structures were also examined via Turkish National Corpus by checking 6 distinct words namely, beddua, ilenme, kargış (curse), bela (evil, trouble), kahretsin (damn) and mahvetsin (may god ruin). As a result of the search, 99 dependent indexes were obtained for the word Beddua (curse), 763 for Bela (evil, trouble), 3 for Ilenme (meladiction), 334 for Kahretsin (Damn) 13 for Karglş, and only 2 for Mahvetsin. Furthermore, some additional cursing structures such as lanet olsun and lanet gelsin (curse him), evi yık1lsin (may destroy...house), evi yansin (may his house burn), parçalanasın (go into pieces), belanı bul (find trouble), Allah cezanı versin (may god give your punishement), cezanı bul (find your punishment), ah etme (cursing) were also queried on corpus yet there were no matches. After the subordinate features shown in transcribed (eg curse), some dependent structures containing their use in index were removed, (e.g trouble maker) for evilness as they had distinct meaning than cursing in context. Table 1, Table 2, Table 3 and Table 4 show some of the dependent indexes of the words curse, evilness, malediction and damn, respectively.

Table 4. the concordance samples of the word beddua (curse) on corpus

\begin{tabular}{|r|c|l|}
\hline üstünde görürüm seni inşallah! diye & beddua & eden babasının sesi tavana çarparak \\
\hline ülke gibiyiz. Hani insan insana & beddua & eder "Allah seni bilmem ne \\
\hline örnekleriyle. Bu "Tanrı", inanmayanlara, kızdıklarına & beddua & da eder. Yani ilenir. Mantıkta, \\
\hline ölsün diye dua ettim görümceme & beddua & ettim rüyamda sonra duam tutmuş \\
\hline çatlasın Nazar eden patlasın" diye & beddua & ederler. Bazı yerlerde de yaygın \\
\hline yorumlarında belirtildiğine göre, burada kınanan, & beddua & edilen kimse, Muğire Oğlu Velid'dir. \\
\hline
\end{tabular}

\begin{tabular}{|l|}
\hline I hope next time I see you dead! the voice of his father, who curse, slams on the ceiling \\
\hline we are like a country. Behold, it makes people curse "God, I don't know what \\
\hline with examples. "God" also curses those who do not believe, who he is angry with. So he maledicts. Logically, \\
\hline I prayed for my sister-in-law to die, I cursed her in my dream, and later my prayer came true \\
\hline Some people curse that may those who have devil eyes blow up, it is also common in some places. \\
\hline As stated in his comments, the one who is condemned and cursed here is Muğire Son Velid. \\
\hline
\end{tabular}


The term Beddua (curse) was observed on 70 texts with a frequency of 99 , nevertheless the statements including curse structures were a number of (14);

1. Bir daha sal üstünde görürüm seni inşallah (I hope next time I will see you in a coffin)

2. Allah seni bilmem ne yapsin (May God make you I do not even know what)

3. Kem göz çatlasın nazar eden patlasın (let sinister eye envy, let one who has evil eye blow up)

4. Bu kötülüğ̈ yapanların elleri kırılsın (may the hands of those who do this evil be broken)

5. Haram olsun sana verdiğim emekler (May you get no benefit from it)

6. Kocan ölsün! (may your husband die)

7. Allah size türkiye gibi komşular nasip etsin (God bestowed on you neighbors like Turkey)

8. "rahmetli dayım birine beddua edeceksen kiracın olsun de derdi" (may you have a tenant)

9. Taşına topră̆ına güller dolsun (may roses grow on your soil and stone)

10. Canı çıksın, O ne nankördür (damn him, what an ungrateful he is)

11. Inşallah o şaşırtıcı zamana rastgelesiniz (I hope you come across that bewildering time).

12. Kendi çocuğun da sana çeker inşallah (I hope your own child take after you too)

13. Kahrolsun, gebersin, başı kopsun (damn it, peg out, let his head come off)

14. Melun oğlu melun (son of a cursed).

The word Bela was the most common word among all 6 words related to cursing structures queried with a number 493 in written or verbal texts with a total of 763 observed frequencies. Despite being very common, the word Bela was detected semantically unrelated meanings to cursing such as causing trouble, creating someone a big problem, scarcely and with difficulty etc. there is only 2 structures as followings;

i. öylece çömeliyorum, tutamıyorum kendimi, iğrenç, bela, Allahın cezası tozun üstüne gözyaşlarını- (just crouching, I can't hold myself, disgusting, trouble, tears on God damn dust)

ii. Allah kaza bela vermesin! (May god not let any trouble or accident happens).

Table 5. The sample concordance of the word bela (trouble) on corpus

\begin{tabular}{|l|l|l|}
\hline Charli, Charli, Charli, Çifte Çifte & Bela & Bela gibi yabancı Bela yapımların benzerleri \\
\hline şüphelenir, her taşın altında bir & Bela & arar, her yerde bela düşmanlar, dertler \\
\hline şöyle bir bakabilmişlerdi içeriye. Güç & Bela & dedeyi salona sokup bela bir koltuğa \\
\hline şu an 288. inci yedi & bela & maddeyi eleştirmem de bela) suç kapsamına \\
\hline şişman kıçını koltuklardan birine güç & bela & Sı̆̆gdırmış, hiç kımıldamadan, bela alık alık \\
\hline şirketi olsaydı; yönetim kurulumuzda da & bela & bir amca çocuğu bela oturuyor olsaydı \\
\hline
\end{tabular}

Charli, Charli, Charli, Double Double trouble similar to foreign Bela productions

suspects, searches for a trouble under every stone, troubles, enemies, problems everywhere

They could look inside. With great difficulty put the grandfather in the hall and get him into a seat

It is also trouble for me to criticize the 288 th seven items of trouble currently. 
He put his fat ass into one of the seats hardly, without moving, trouble stupidly

if he had a company; if there was trouble cousin sitting in our board of directors

Table 6. The sample concordance of the word ilenme (cursing) on corpus

\begin{tabular}{|l|l|l|}
\hline gittikleri gün bile, ağzından bir & İlenme & bir yakınma cümlesi çıkmamıştı. Yalnızca \\
\hline bu delikanlılarla gençkızlar bir yandan & İlenme & çemkirme, gözdağı, nispet, hakaret, çekişme \\
\hline Arapça'dır. "Kötü dua" demektir. Türkçesi & İlenme & ya da "ilenç". Kur'an'ın "Tanrı"sının \\
\hline
\end{tabular}

Even the day they were gone, a sentence of curse or complain did not come out of his mouth. Only these youngsters and young girls on the one hand teckling, intimidating, envying, insulting, strifing İt is in Arabic. It means "bad prayer""ilenç in Turkish ". Of the "God" of the Quran

Ilenme was identified merely 3 and none included any imprecation in Corpus.

Table7. The sample concordance of the word kargış (meladiction) on corpus both in Turkish and English

\begin{tabular}{|l|l|l|}
\hline beylerin alkışı alkış, kargışı & kargış & idi. Duaları müstecap olurdu" Burada \\
\hline aldatıcı görüntülere, tatlı zehirlere & kargış & ama hepsinden önde, bütün bunlara \\
\hline giden benine kargış, kendine & kargış & "Aman rabbim" olur mu hiç, \\
\hline giden benine kargış, kendine & kargış & "Aman Rabbim" olur mu hiç, \\
\hline dolaşımdadır. Diğer bir karış, & kargış & lanet" anlamına gelir. Karış görmek \\
\hline bunlara kapılıp giden benine & kargış & kendine kargış... "Aman Rabbim" olur \\
\hline
\end{tabular}

\begin{tabular}{l} 
The applause of the gentlemen was applause, and their meladiction was curse. His prayers would be obscene \\
"Here \\
\hline maledict to deceitful images, to sweet poisons but ahead of all, to all these \\
\hline Meladiction to the person going, to himself "Oh my Lord" does it happen? \\
\hline Meladiction to the person going, to himself "Oh my Lord" does it happen? \\
\hline it is in circulation. Malediction means "curse." \\
\hline Meladict to me, who get caught up in them, maledict to yourself... Could it be "My Lord"?
\end{tabular}

Kargıs was recognized with the frequency of 13, yet none of them contained imprecation.

Table 8. The sample concordance of the word kahretsin (damn) on corpus

\begin{tabular}{|l|l|l|}
\hline şöyle biraz tırmala. O, 'Allah & Kahretsin & yine pantolonumu mahvetti bu kedi, \\
\hline şu, bundan bu... Hay allah & Kahretsin & Elleri titreyerek zarfı yırttı. Çıkan \\
\hline şişe bira kalmış... Tüh, Allah & Kahretsin & bunu da ne zaman içmişim? \\
\hline şey oldu," diye homurdandı. "Allah & Kahretsin & "N'oldu?" "Sabah evden çıkarken, eczacı \\
\hline şey arıyordu motorun içinde. "Allah & Kahretsin & diye söylendi. "Cep telefonumu şantiyede \\
\hline
\end{tabular}

scratch a little like this. He said, 'Damn it, this cat ruined my pants again,

this, from that this ... Oh god Damn tore the envelope his hands trembling and the thing...

bottle of beer left ... Oops, damn, when did I drink this?

something happened, "he grunted." God damn it "What happened?" "When I was leaving home in the morning, the pharmacist

looking for something inside the engine. "God damn it."he complained.. "My mobile phone is on the construction site 
The term Kahretsin (damn) was observed 334 times with a second highest frequency among 5 other tokens but with distinction of all statements either included of cursing "god damn " (you, me or him) or “damn."

Table 9. The sample concordance of the word mahvetsin (ruin) on corpus

\begin{tabular}{|l|l|l|}
\hline kendisine isyan etsin ve insanları & mahvetsin & diye onu? Bilmiyorsa İblis'in yapısını \\
\hline bir sel gibi Asi İskoçları & mahvetsin & Tanrı kraliçeyi korusun! Kanada, Yeni \\
\hline
\end{tabular}

to revolt him and ruin people? If he doesn't know, the feature of devil

May ruin the rebel Scots like a flood, God bless the queen! Canada, New

Mahvetsin (god ruins it) is another term coined with a reduced frequency of two, merely one of which consisted of cursing structure as in "bir sel gibi asi iskoçları mahvetsin, tanrı kraliçeyi korusun" (may god ruin rebellious Scottish like a flood, god bless the queen).

\section{Discussion and Conclusion}

In this study, we attempted to discover what the unique features of curse utterances and the most frequent curse utterances there were in Turkish and how they differed across regions, as well as whether social variables such as age, gender, and education level influence which curse structures were used, and whether survey results were parallel with curse utterances employed in the Turkish National Corpus.

The results of the current study revealed that gender age and education level did not have any influence on whether the participants curse. While gender and education level has no effect on the situation participants use imprecations, age had a significant effect. All the three demographic variables tested in this study had significant effect on the perception of the reason for cursing and curse utterances they mostly use.

We have found that participants in the survey rarely used positive utterances such as Allah iyiliğini versin (God give goodness) and Allah belanı kaldırsın (may god let you get rid of trouble). Instead of negative words and sentences, they reported that they utter positive statements. Allah kaza bela vermesin! (May god do not let/cause any trouble) was used in corpus yet it is positive not negative 
as in cursing structures. Allah tependen baksin is another expression used by respondents to reflect anger without curse and wishing trouble.

When the findings of survey and corpus results compared, the survey indicated more comprehensive results in terms of variety of cursing utterances used by participants some of which match to Allah seni kahretsin, Kahretsin (God damn you, damn it). While May Allah (God) punish you did not appear in corpus at all, only one example as in "Allahın cezası tozun üstüne" (on to the God punishment dust) the same structure was uttered among the highest frequencies in survey. The other term "bela" was coined by the participants in distinct ways such as "Allah belanı versin" which was the highest frequency and "belanı bul" (find your own trouble). Whereas "bela" took place 493 different written or verbal texts and observed 763 times on corpus, only 2 had cursing structures; other words used in unrelated meanings such as causing trouble, creating someone a big problem, scarcely and with difficulty.

Corpuses provide the meanings of a unit and information about how people actually use it. Reviews also serve to determine the collocations of words. With these collocation patterns, repetitive elements in the language and cultural information shared by language users can also be accessed. In this context, different dependent indexes of the words curse structures presented in the Turkish National Corpus are investigated in this study and the collocation patterns were formed. Corpus shows that cursing words beddua-ilenme-kargış (curse, meladiction), kahretsin (damn), mahvetsin (ruin), and bela (trouble) are not only used for expressing negative emotions and behaviors, but also rarely, for expressing positive emotions in the context. Beddua, ilenme, kargış are mostly defined in contexts with the information of who curses to whom e.g., "Ne olursa olsun analar çocuklarına beddua etmemeli" (Regardless, mothers should not curse their children) or "Babam kardeşime beddua etti" (my father cursed my brother) and only 14 out of 99 observed frequencies for beddua (curse) actually comprise cursing utterances as explained above e.g., Haram olsun sana verdiğim emekler (May you get no benefit from it). In general, the word beddua (curse) is used as both positive and negative sentences such as, çok beddua ettim (I cursed a lot), Sana hiç beddua etmedim (I have never cursed you), Bu sebepten kimseye beddua etme (because of this, never curse anyone), and Kendi şahsi için en zor durumlarda bile beddua etmemiştir (he never cursed for himself even in the most difficult situations).

Illenme and kargls are also the other words to refer cursing as beddua. Although both words are 
detected on corpus with frequencies of 3 and 13, respectively, none contained cursing. It is most likely the result of survey and corpus match on the word mahvetsin (May god ruin) that it is not commonly used by members of speech community. Kahretsin however, is used for cursing $1^{\text {st }}$ person, $2^{\text {nd }}$ and $3^{\text {rd }}$ person (damn me, you, him) or sometimes for the unfortunate events and bad things experienced through corpus e.g., Allah seni kahretsin sözleri döküldü (words of "God damn you" spilled from his/her mouth), öyle dediyse Allah onu kahretsin (if he said so God damn him), and Allah beni kahretsin ne alçak biriymişim ki (God damn me what a villain I am).

One parallel finding with the study Atmaca conducted in 2019 is that there is a state of trust in Allah and referring to Him. The structures do not consist of very long sentences as common words are used to describe. Beyazit, (2019) pointed that in the event that physical power is not sufficient, the existence of a spiritual power is accepted and the person responds by requesting help from the mighty forces. Concomitantly, our survey result shows similarity in that the preference the reason why people curse was because they feel desperate and helpless. Another similarity we observe is that curse structures mostly directed to the "target person-you" (addressee not the speaker) displaying resemblance to categorization by Ersöz (2011) as the "target person" who could be "you (anyone else but the speaker)", "I (the speaker himself)" or "nobody" and the "context" in which the bad wish in the curse was directed and the curse functions as full curse there is only a few curses like prayer. Curses defined in terms of context in which participants use and texts took place in National Corpus are mostly about death, disease and oath as Atmaca (2019) categorized based on context.

Austin describes the curse as an articulation of emotion that falls beyond the definitions of the locutionary, the illocutionary or the perlocutionary. he ascribes "cursing" to the category of "behabitants." Behabitives are related to attitudes and social behavior."They" require the notion of reaction to the actions and of attitudes and expressions of actions towards someone else. The variations attained from the current study are unique reactions to person or situation that cause trouble to the addressor producing a speech act.

Cursing is one of the 'behabitants' meanings that it must be understood as a social act, and it must be understood in the socio-cultural sense. Curse utterances can thus help to understand a community of people's cultural identity, belief system and thought ways. 


\section{REFERENCES}

Aksan, Y., Aksan, M., Koltuksuz, A., Sezer, T., Mersinli, Ü., Demirhan, U. U., Yılmazer, H., Atasoy, G., Öz, S., \& Y1ld1z, İ. (2012). Construction of the Turkish national corpus (TNC). Proceedings of the Eighth International Conference on Language Resources and Evaluation (LREC'12), 3223-3227.

Atmaca, E. (2019). Antalya Ağizlarinda Dua Ve Beddualar. Avrasya Uluslararası Araştırmalar Dergisi, 7(19), 42-80.

Beyazıt, D. Y. (2019). Karacaören Köyü Halkiyat Ve Harsïyatindan Bir Nebze: Kargişlar Ve Alkişlar. Harsiyât, 3(5).

Biber, D. E. (2012). Corpus-based and corpus-driven analyses of language variation and use. In The Oxford handbook of linguistic analysis. Oxford University Press.

Devi, C. S. (2019). An Ethno-Linguistic Study of Curse Utterances in Meitei Society of Manipur.

Ersöz, S. (2011). Türkiye Türkçesinin Doğu Grubu Ağizlarinda Beddualarin İşlevleri Ve Cümle Yapilari Arasindaki İlişki. Electronic Turkish Studies, 6(1).

Keskin, A. (2019). Alkışların (Dua/İyi Dilek) Ve Kargışların (Beddua/Kötü Dilek) Terim, Tanım Ve Tasnif Problemlerine Bağlam Merkezli Bir Yaklaşım.

Mertens, D. M. (2014). Research and evaluation in education and psychology: Integrating diversity with quantitative, qualitative, and mixed methods. Sage publications.

Nezakat-Alhossaini, M., \& Esslami-Rasekh, A. (2013). "May Bread Run and You Run After It": The Function of Cursing in Persian. Procedia-Social and Behavioral Sciences, 70, $517-$ 525.

Strowick, E. (2016). Curse and Modernity: A Brief Introduction. MLN, 131(3), 571-578.

Uysal, Y. (2019). Adıyaman Halk Kültüründe Dua ve Beddualar (Alkışlar-Kargışlar). Türkiyat Mecmuast, 29(2), 17-18.

Vanci-Osam, Ü. (1998). May you be shot with greasy bullets: Curse utterances in Turkish. Asian Folklore Studies, 71-86. 